DOI: 10.12731/2227-930X-2018-4-11-21

UDC 656.025:338.17(571.52)

\title{
METHOD OF PASSENGER TRANSPORTATION MANAGEMENT ON THE EXAMPLE OF REPUBLIC OF TUVA
}

\section{Shavyraa Ch.D.}

One of the priority areas for servicing the population of cities is to provide passengers with high-quality and timely transportation services. The organization of urban public passenger transport is a set of activities whose purpose is to create conditions for favorable movement of the population. The economic and social development of the region depends on the proper organization of the work of urban public passenger transport.

Due to the aging of the vehicle fleet, many city administrations began to attract private carriers that have a small fleet of vehicles. A feature of working with such operators is the difficulty of controlling work on their line. This leads to the creation of a management system for carriers of various forms of ownership. The use of bus tracking systems on the line has become a particularly urgent problem in small towns.

Creating a universal structure of the management system for carriers of various forms of ownership is important for small cities and urban-type settlements, since most of the population in such cities use public transport.

Purpose. Creation of a universal structure of a control system for operators of various forms of ownership.

Methodology. The article used automated control systems. As a control object, operators of various forms of ownership were used.

Results Universal structures of automated control systems were obtained. Combined with the formulas for optimizing the time of work on the line will allow to draw conclusions about the resource-intensiveness of the system, the degree of expediency of investing funds in each 
area of activity to improve the organization of transport services for the population, the degree of compliance with the standards for passenger traffic and the size of compensation various activities.

Practical implications. The management system allows you to disclose the principles of solving problems that are common to the entire set of activities for the organization of passenger transport.

Keywords: structure; passenger; vehicle; carriers; model.

\section{МЕТОДИКА УПРАВЛЕНИЯ ПАССАЖИРСКИМИ ПЕРЕВОЗКАМИ НА ПРИМЕРЕ РЕСПУБЛИКИ ТЫВА}

\section{Шавыраа Ч.Д.}

Одним из приоритетных направлений по обслужсиванию населения городов является предоставление пассажирам качественных и своевременных услуг по перевозке. Организация работы городского общественного пассажсирского транспорта - это комплекс мероприятий, целью которых является создание условий для благоприятного передвижения населения. От правильной организации работы городского общественного пассажирского транспорта зависит экономическое, социальное развитие региона.

В связи старением парка транспортных средств многие Администрачии городов стали привлекать частных перевозчиков, которые имеют небольшой парк транспортных средств. Особенностью работы с такими операторами является трудность контроля работы на их линии. Это обусловливает создание системь управления перевозчиками различных форм собственности. Применение систем слежения работы автобусов на линии стал особо актуальной проблемой в мальх городах.

Создание универсальной структуры системы управления перевозчиками различных форм собственности является важным для малых городов и поселков городского типа, т.к. большая часть населения в таких городах пользуются общественным транспортом. 
Цель. Создание универсальной структуры системы управления операторами различных форм собственности.

Метод или методология проведения работы: в статье использовались автоматизированные системы управления. В качестве объекта управления применялись операторы различных форм собственности.

Результаты: получены универсальные структуры систем автоматизированного управления. Совместное использование $c$ формулами по оптимизации времени работы на линии позволят делать выводы о ресурсоемкости системы, о степени целесообразности вложения средств по каждому направлению деятельности по повышению организации транспортного обслужсивания населения, о степени выполнения норм по пассажирским перевозкам и о размерах компенсаций, штрафов, других видов стимулирования различных видов деятельности.

Область применения. Система управления позволяет раскрыть принципы решения проблемы, которые являются общими для всего множества деятельности по организаџии пассажирских перевозок.

Ключевые слова: структура; пассажир; транспортное средство; перевозчики; модель.

Currently, three quarters of the population of the Republic of Tuva live in cities. Urban public passenger transport (GPT) carries more than 72 thousand passengers daily. Stable operation of this sector of the economy, which provides about $65 \%$ of labor and household trips in urban and suburban communications, is of exceptional social importance for the Republic of Tuva [12].

In recent years, public passenger transport is experiencing a crisis due to the trend of decline in traffic. Its main reasons are the decline in the quality of transport services, the increase in the level of motorization, the change in the structure of demand for transport services, the development of commercial passenger transport, the aging of the vehicle fleet (TC). The situation when the effective demand for trans- 
port services is met by private commercial transport, and the transportation of preferential categories of the population falls on municipal transport, leads to a reduction in revenues from transportation and an increase in the need for budget financing. This problem is particularly acute in small towns and urban settlements, where public transport is on the verge of extinction due to limited financial resources of municipal authorities [12].

The main disadvantages of the existing organizational structure of transport services at the GPT in small towns and urban settlements are:

- lack of organizational support for necessary but unprofitable services;

- low quality and not efficient work of municipal carriers because of the lack of motivation of their work;

- lack of investment opportunities - limitation of opportunities to develop services and upgrade the basic tools;

- oversupply of transportation services on profitable routes;

- a sharp deterioration of the environment and the decrease of safety on serviced routes;

- lack of coordination between carriers of different forms of ownership [12].

This article discusses the basics of managing carriers of all forms of ownership.

In addition to ensuring priority for public transport, many cities faced the need to change the organizational structure of the GPT management. The organizational structure is not the only, although important, factor in the effective management of public transport services. Under the management of transport services is understood a set of actions selected on the basis of certain information and aimed at maintaining or improving the functioning of the object in accordance with the existing program (algorithm), which includes the implementation of known functions: planning, organization, control, etc. [12].

For rice. 1 shows [1] an example of building a structure managed, in particular transportation activities for the organization of the transportation process in small towns and urban settlements. Universality of 
representation of structures of any kind of activity allows to consider Fig. 1 as one of the private "sections" of the total set of activities required to ensure the organization of public service by bus.

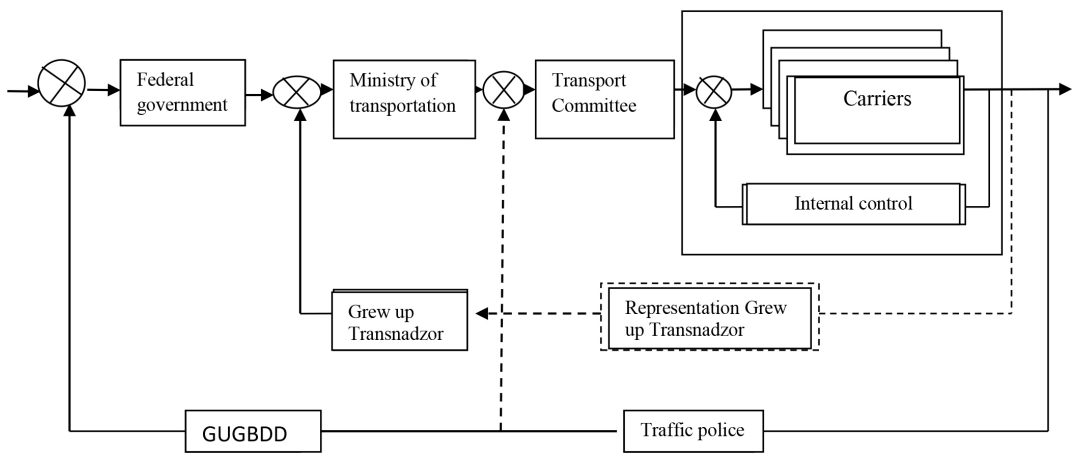

Figure 1. Functional structure of the subsystem of state management of subjects of transportation activity

Formally, the structure of the management system of carriers of various forms of ownership is represented by the transformation of the population's needs for transportation into arrays of their respective goals and meters of the desired result of management. It includes many managed objects (OU) (carriers of various forms of ownership), which are the functional activities of a subject of the system. The accuracy of processing incoming control signals to the input of the Hvh depends on the structure of the output coordinates of the Hvh, controlled by the control system on the feedback channels organized by it. The principle of controllability in any activity is provided by the presence of feedback channels in the structure of the system, which together with the comparison element (ES) provide the development of the program of influence on the DT, eliminating the difference between input and output signals, i.e. provides the required automatism in the system $[8,12]$.

In recent years, the Era-GLONASS system has been installed on many vehicles to control the work of carriers of various forms of ownership working on the routes of Kyzyl [14]. This system allows you to control the work of carriers. Before the introduction of the system, 
the population and the city administration had many problems. Carriers wanted to work only on profitable routes, and on routes with small passenger traffic they took a "day off".

According to the time of day service, to a greater extent, only "rush hours". There were many comments from the population when it is impossible to leave early in the morning (before $7 \mathrm{am}$ ), and late in the evening (after 20 hours). On routes Kyzyl work a lot of private carriers with fleet of vehicles of small capacity. Most of the vehicles used are Gazelle minibuses. At peak times there are constant Overdrive, it is impossible to go from p. G. T. Kaa-Khem, left Bank cottages, with the right Bank cottages, the village, the Middle of Kaa-Khem river, etc.

Figure 2 shows a generalized model of the activities of carriers of different forms of ownership.

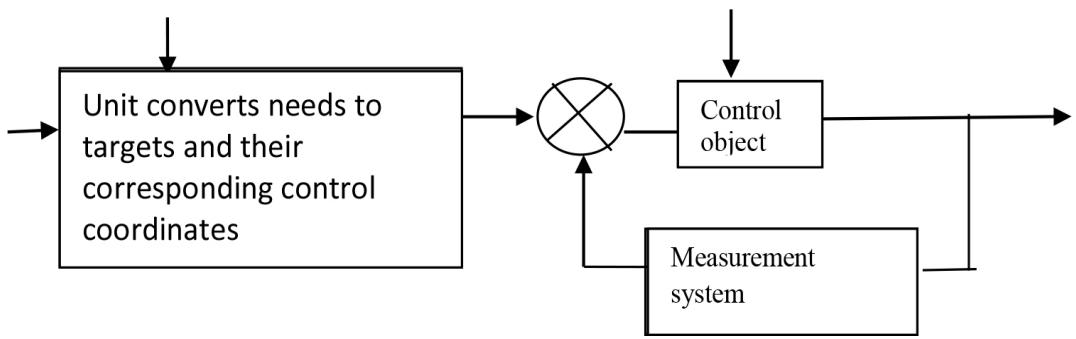

Figure 2. The generalized model of activity of carriers of various forms of ownership used for justification of system of estimates of its efficiency

where; $\mathrm{P}$ - needs of society; OU - object of management; ES-element of comparison

The physical meaning of the input signals-measures to improve the organization of public transport services by bus, including commands (orders, instructions, laws, strategies), resources (material and financial), etc.Output signals - indicators of the result of the operation of individual units of the system (intermediate coordinates) and the system provided the overall level of public service (controlled coordinate) [2].

The object of OU control can be characterized by a set of $\mathrm{W}$ input-output pairs. Then the model of activity of any object of management is defined by the following three: 


$$
\mathrm{K}=(\mathrm{CVC}(\mathrm{t}) \text {, coniferous }(\mathrm{t}),(\mathrm{W}),
$$

Where: $\mathrm{W}-$ is the ratio that determines the dependence of the output on the input.

a) Indicator of organizational effectiveness of the public service system-the ratio of the actual level of service to the standard:

$$
\mathrm{K} 1=\mathrm{Hfac} / \mathrm{h} \text { norms }
$$

b) Indicator of minimization of time spent by passengers on urban routes;

$$
\mathrm{K} 2=\sum \mathrm{Qij} * \mathrm{Tij} \rightarrow \min ,
$$

C) the indicator of the calculated capacity of PS on each route:

$$
\mathrm{K} 3 \text { = Qij mah* I, }
$$

d) Indicator of the number of buses to operate on each route: $\mathrm{K} 4=$ тоб $/ \mathrm{I}=(2 * \mathrm{LM}) /\left(\mathrm{V}^{*} \mathrm{I}\right)=\left(2 * \mathrm{LM}^{*} \mathrm{Qij}\right.$ мax $) /\left(\mathrm{V}^{*} *\right.$ q расч $),(1.5)$

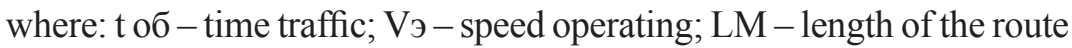

The accumulation of static material on these indicators for all subjects of the system will allow to draw conclusions about the resource intensity of the system, the degree of expediency of investing in each area of activity to improve the organization of transport services of the population, the degree of implementation of standards for passenger transportation and the amount of compensation, fines, and other incentives for various activities [15].

A large amount of required system research and development from the level of the entire system to the structure and functions of each of its constituent elements, different level of influence on passenger transportation individual functional blocks make appropriate methodological formulation and solution of the problem of evaluating the effectiveness of the system of organization of passenger transportations with an i1lustration of its application on the example of one type of constituent entities of the organization of the service of the population of bus transport. The usefulness of the methodological statement is explained by the fact that it allows to reveal the principles of solving the problem, which are common to the whole set of activities for the organization of passenger transportation.

In modern conditions, there are often situations when it becomes difficult to fly right on schedule due to the influence of many factors on 
the movement of rolling stock. Nevertheless, it is necessary to strive for the use of advanced software tools and methods organization, management, monitoring and coordination of passenger traffic [5-7].

The city of Kyzyl is characterized by spontaneous, unregulated movement of buses of all forms of ownership. Timely and high-quality provision of services in this case plays an important role. When moving passengers in urban transport quality indicator is a quantitative characteristic of one of the properties that make up the quality of passenger traffic, considered in relation to certain conditions of their organization and implementation [4].

For the carriage of passengers by buses MUP "Kyzyl" in the first place it is necessary to pay attention on traffic safety. Basically, this company can attract passengers with new buses, competently compiled schedule, more attractive prices and qualified drivers of a certain category. There were many road accidents involving Gazelle minibuses, in some cases even fatal. Therefore, the organization and management of transportation is an important factor-the causes and the road network in which accidents occur.

The key term in the problem of OBD is "causes of accidents".

Knowledge of their full set and mechanisms of prevention are the basis of science ensuring "zero mortality on the roads" $[1,10]$ and implementation of its concepts in real life practice $[3,9,11]$.

The application of the functional structure will allow you to control the carriers of different forms of ownership, to draw conclusions about the carrying capacity of the system to propose measures to improve the organization of public transport services bus transport in small towns and urban-type settlements. Competitive selection of Carriers will ensure safety, timeliness and proper quality of services.

\section{References}

1. Evropeyskiy doklad o bezopasnosti dorozhnogo dvizheniya [European Road Safety Report]. Kopengagen: VOZ, 2009, pp. 6-7.

2. Fedorov V.A., Kravchenko P.A. Materialy 3-y mezhdunar. konf. «Organizatsiya i bezopasnost'dorozhnogo dvizheniya v krupnykh gorodakh 
[Materials of the 3rd international. conf. "Organization and road safety in large cities]. SPb., 1998, pp. 11-17.

3. Gamulin A.G. et al. Avtomatizatsiya upravleniya bezopasnost'yu poletov [Automation of safety management]. M.: Transport, 1989. $116 \mathrm{p}$.

4. Gorev A.E., Opeshchenko E.M. Organizatsiya avtomobil'nykh perevozok i bezopasnost' dvizheniya [Organization of road transport and traffic safety]. M.: Knorus, 2006. 256 p.

5. Semchugova E.Yu., Negrov N.S. Nauchnoe obozrenie, № 9, part 3. 2014, pp. 1022-1026.

6. Semchugova E.Yu., Negrov N.S. Inzhenernyy vestnik Dona, 2013, №4. http://www.ivdon.ru/magazine/archive/n4y2013/2192

7. Zyryanov V.V., Semchugova E.Yu., Skrynnik A.M. Inzhenernyy vestnik Dona, 2012, №4 (part 1). http://www.ivdon.ru/magazine/archive/ n4p1y2012/1083

8. Kravchenko P.A., Oleshchenko E.M. Transport Rossiyskoy Federatsii. 2015, pp. 25-31.

9. Safe Traffic - Vision Zero on the move. Swedish Transport Administration, 2012.

10. Otchet o sostoyanii bezopasnosti dorozhnogo dvizheniya v mire [Report on the state of road safety in the world]. Zheneva: 2015, pp. 4-6.

11. The representative of the Israeli police all traffic is controlled from the center. M. "Stop-Gazeta”. 2005. № 5, pp. 10-12.

12. Shavyraa Ch.D., Mongush S.Ch. Vestnik Moskovskogo avtomobil'nodorozhnogo instituta (Gosudarstvennogo tekhnicheskogo universiteta). 2009. №2(17).

13. Shavyraa Ch.D. Razrabotka metodiki organizatsii obsluzhivaniya naseleniya avtobusnym transportom $v$ malykh gorodakh. Avtoreferat dissertatsii na soiskanie uchenoy stepeni kandidata tekhnicheskikh nauk [Development of methods of organizing public services by bus transport in small towns. Abstract of dissertation for the degree of candidate of technical sciences], 2009.

14. Shavyraa Ch.D. Mir transporta. V. 16, №6 (79), pp. 146-152.

15. Shavyraa Ch.D., Gorev A.E. Avtotransportnoe predpriyatie. 2009. №2, pp. 18-20. 


\section{Список литературы}

1. Европейский доклад о безопасности дорожного движения. Копенгаген: ВОЗ, 2009. С. 6-7.

2. Федоров В.А. Кравченко П.А., Модель системы государственного контроля выполнения норм безопасности дорожного движения// Материалы 3-й междунар. конф. «Организация и безопасность дорожного движения в крупных городах / СПбГАСУ. СПб., 1998. C. $11-17$.

3. Гамулин А.Г. и др. Автоматизация управления безопасностью полетов. М.: Транспорт, 1989. 116 с.

4. Горев А.Э., Опещенко Е.М. Организация автомобильных перевозок и безопасность движения / А.Э. Горев, Е.М. Олещенко. М.: Кнорус, 2006. 256 с.

5. Семчугова Е.Ю., Негров Н.С. Обеспечение мобильности населения в системе городского пассажирского транспорта // Научное обозрение, № 9, часть 3. 2014. С. 1022-1026.

6. Семчугова Е.Ю., Негров Н.С. Анализ функционирования городского пассажирского транспорта с использованием программного комплекса «Pikas» // Инженерный вестник Дона, 2013, №4. Режим доступа: http://www.ivdon.ru/magazine/archive/n4y2013/2192

7. Зырянов В.В., Семчугова Е.Ю., Скрынник А.М. Применение информационных технологий при повышении мобильности и обеспечении транспортной безопасности [Электронный ресурс] // Инженерный вестник Дона, 2012, №4 (часть 1). Режим доступа: http:// www.ivdon.ru/magazine/archive/n4p1y2012/1083

8. Кравченко П.А., Олещенко Е.М. Концепция полной наблюдаемости систем обеспечения безопасности дорожного движения // Транспорт Российской Федерации. 2015 Спец. Выпуск. С. 25-31.

9. Safe Traffic - Vision Zero on the move. Swedish Transport Administration, 2012.

10. Отчет о состоянии безопасности дорожного движения в мире. Женева: 2015. С. 4-6.

11. The representative of the Israeli police all traffic is controlled from the center. M. "Stop-Gazeta”. 2005. № 5, pp. 10-12. 
12.Шавыраа Ч.Д., Монгуш С.Ч. Построение структуры управления перевозочной деятельностью по организации работы общественного транспорта в малых городах // Вестник Московского автомобильно-дорожного института (Государственного технического университета). 2009. №2(17).

13. Шавыраа Ч.Д. Разработка методики организации обслуживания населения автобусным транспортом в малых городах. Автореферат диссертации на соискание ученой степени кандидата технических наук / Санкт-Петербургский государственный архитектурно-строительный университет. Санкт-Петербург, 2009.

14.Шавыраа Ч.Д. Диспетчерское управление работой автобусов // Мир транспорта. М.: Мир транспорта. Т. 16, №6 (79). С. 146152.

15.Шавыраа Ч.Д. Организационные преобразования в сфере городского пассажирского транспорта в городе Кызыле Республики Тыва / Ч.Д. Шавыраа, А.Э. Горев // Автотранспортное предприятие. 2009. №2. С. 18-20.

\section{DATA ABOUT THE AUTHOR}

Shavyraa Chechek Despi-oolovna, Associate Professor of the Department of Transport and Technological Means, Candidate of Technical Sciences

Tuva State University

36, Lenin Str., Kyzyl, Republic of Tyva, 667000, Russian Federation

Shavyraa@mail.ru

\section{ДАННЫЕ ОБ АВТОРЕ}

Шавыраа Чечек Деспи-ооловна, доцент кафедры «Транспортно-технологические средства, кандидат технических наук. ФГБОУ ВО Тувинский государственный университет ул. Ленина 36 г. Кызыл Республика Тьвва, 667000, Российская Федераичи Shavyraa@mail.ru 